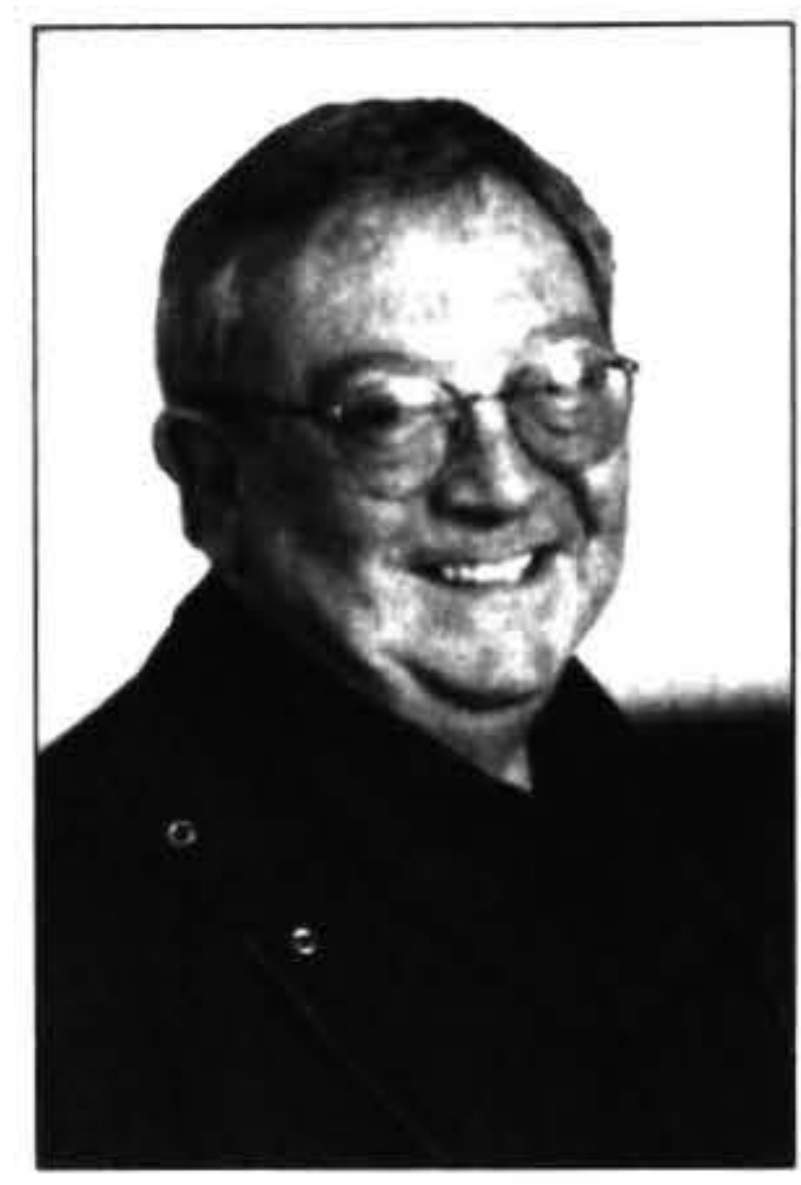

\title{
EMPLOYERS, UNIONS AND \\ WORKPLACE PARTNERSHIP \\ IN NEW ZEALAND
}

\author{
Ian McAndrew
}

Department of Management, University of Otago, Dunedin

\begin{abstract}
In 2005 the Partnership Resource Centre of the Department of Labour commissioned a comprehensive review or stocktake' of union-management workplace partnership practices and hehaviours in New Zealand. The study found that the penetration of partnership practices has heen sporadic and/or experimental, set in an environment that is oftentimes ahrasive to the concept. Nonetheless, in many workplaces where collective bargaining has existed for a significant period. hoth unions and management are adopting some kev features of a partnership approach. The study concluded that prospects for further penetration of partnership behaviours in unionized firms are positive as the attitudes of many officials on hoth sides are relatively open to the approach and to the practices it encompasses. This paper offers empirical insights into the attitudes and hehaviours of New Zealand employers and union officials in single-emplover collective hargaining relationships regarding collective hargaining, other consultative measures. as well as collahorative versus competitive approaches to their relationships with one another.
\end{abstract}

\section{Introduction}

This paper is the product of a significant research project sponsored by the Partnership Resource Centre (PRC) in the New Zealand Department of Labour (DOL). The PRC sought to describe the current state of workplace partnership in New Zealand employment relations by documenting and analysing contemporary employerunion relationships in action (Ballard \& McAndrew 2006).

The core ideas behind partnership include: a collaborative approach to bargaining; wide union and employee consultation practices: a focus on extracting "mutual gains" from negotiations; a preference for consensus over conflict: and, mutual investment in protecting relationships. Partnership nonetheless respects the existence of a diversity of interests in the workplace, recognizes the potential for legitimate conflict there, but promotes restraint and protection of the relationship in the management of conflict.

The study involved a comprehensive review of all relevant New Zealand literature and documented case studies. With that background, a theoretical model identifying the antecedent behaviours involved in workplace partnership was developed and from that a structured questionnaire and survey process was completed. This paper summarises the results of the study, with a focus on the survey outcomes.

\section{Workplace Partnership Theory and Practice}

The term workplace partnership incorporates a range of cooperative practices from societal to workplace levels. Today's interest in partnership arguably derives from several quite diverse concepts and practices.

One is the unitarist framework embodied in the employerinitiated, union-excluding "employee involvement" or "employee participation" schemes popularised in Britain and the United States, among other countries, in the 1980s (Marchington \& Wilkinson 2000; Wilkinson 2001). Today, they are often supported by a strongly unitarist managerial rhetoric and a sophisticated suite of high commitment human resources management practices designed to "win minds and hearts" to organizational goals (Guest \& Peccei 2001).

In more direct lineage to modern union-management partnerships are several pluralist strands, including one that flows from the post-World War II Western tradition of collective bargaining studied by Bakke and other institutional labour market scholars in the 1940s, 50 s, $.60 \mathrm{~s}$ and $70 \mathrm{~s}$, particularly in the United States and Britain (Bakke 1946; Flanders 1974; Clegg 1979; Brannen 1983).

This tradition is what has been referred to as:

... a minimal pluralist-volumtarist sense of partnership as a stable. collaborative relationship between capital and labour, as 
represented by an independent union, providing for low social conflict and significant worker influence on business decision-making through strong collective bargaining (Ackers \& Payne 1998: 533).

This is essentially voluntary, collective bargaining-based cooperation between management and union, with an acknowledgement of some differences of interest between employer and employee, and an acknowledged role for the union as representative of workers, albeit with a deemphasis on the sort of sustained, overt industrial conflict that often characterized collective bargaining in earlier times and a greater emphasis on seeking consensus through integrative bargaining.

The second relevant pluralist concept is that of "industrial democracy" as embodied in, for example, European Works Councils. The third is partnership in the state corporatist sense, again with roots in Northern Europe and Scandinavia.

While New Zealand has toyed with these latter two concepts, it is really the "voluntarist pluralist" concept of state-enabled, but not mandated, collective bargaining, perhaps with subsidiary consultation mechanisms, and incorporating an independent union voice for employees that would likely offer the most fruitful foundation for workplace partnership in this country. This is essentially the "mutual gains" approach advocated by Kochan and Osterman (1994).

\section{The New Zealand Experience}

For 90 years until the mid-1980s, the New Zealand labour market operated under a compulsory conciliation and contingent arbitration model for the setting of wages and conditions. Though there were some exceptions, this centralised and low-involvement model offered little opportunity for the development of collaborative workplace relationships between unions and managements.

The Labour Relations Act 1987 (LRA) was intended to provide stimulus to further breaking down the awardbased structures that had been stripped of arbitration backing in 1984, and to experimentation with industry- or enterprise-based, collective bargaining (Harbridge, 1988; Harbridge \& McCaw, 1989; McAndrew, 1989).

In 1989 the government set up a Committee of Enquiry into Industrial Democracy, giving further articulation and impetus to the notion that unions should be accepted as constructive partners with business in negotiations at industry and enterprise level (McAndrew, 1989: 137).

The structure and nature of employment relations was soon to change dramatically under the Employment Contracts Act 1991 (ECA).

Employers now had a relatively free hand and made most of the running, and many employees who had previously been covered by union-negotiated awards were moved onto individual employment contracts. The scope of union representation and influence waned considerably.

However workplace reform did occur in pockets of New Zealand industry during the period, mostly in industries exposed to changing global economics, and it included some examples of union-management co-operation.

With its underpinnings being the promotion of collective bargaining and the obligation of good faith dealing, the Employment Relations Act 2000 (ERA) clearly provides more fertile ground for the growth of union-management partnership than did the legislation that preceded it.

The Public Service Association (PSA) Partnership for Quality (PfQ) strategy, implemented in May 2000, was the first explicit and comprehensive attempt by a union in New Zealand to go down a workplace partnership route as a matter of union policy. The PfQ provided a significant impetus for workplace partnership to enter the political and economic agenda, and was a strong catalyst for the government to invest in the Partnership Resource Centre.

There have been occasional high-profile partnership initiatives in the private sector in recent years, perhaps most notably that involving the EPMU and the Dairy Workers Union at Fonterra. But these have come into public view only infrequently, and little was really known about the extent to which partnership-style behaviours and attitudes were prevalent in unionized private-sector workplaces in New Zealand until the present study was commissioned by the PRC.

\section{Methodology}

A theoretical model was developed to extrapolate the behaviours which represent workplace partnership in action, allowing the development of appropriate research instruments to measure the extent and type of partnership behaviours that are occurring in New Zealand at this time.

The research model is shown graphically in Figure 1. 


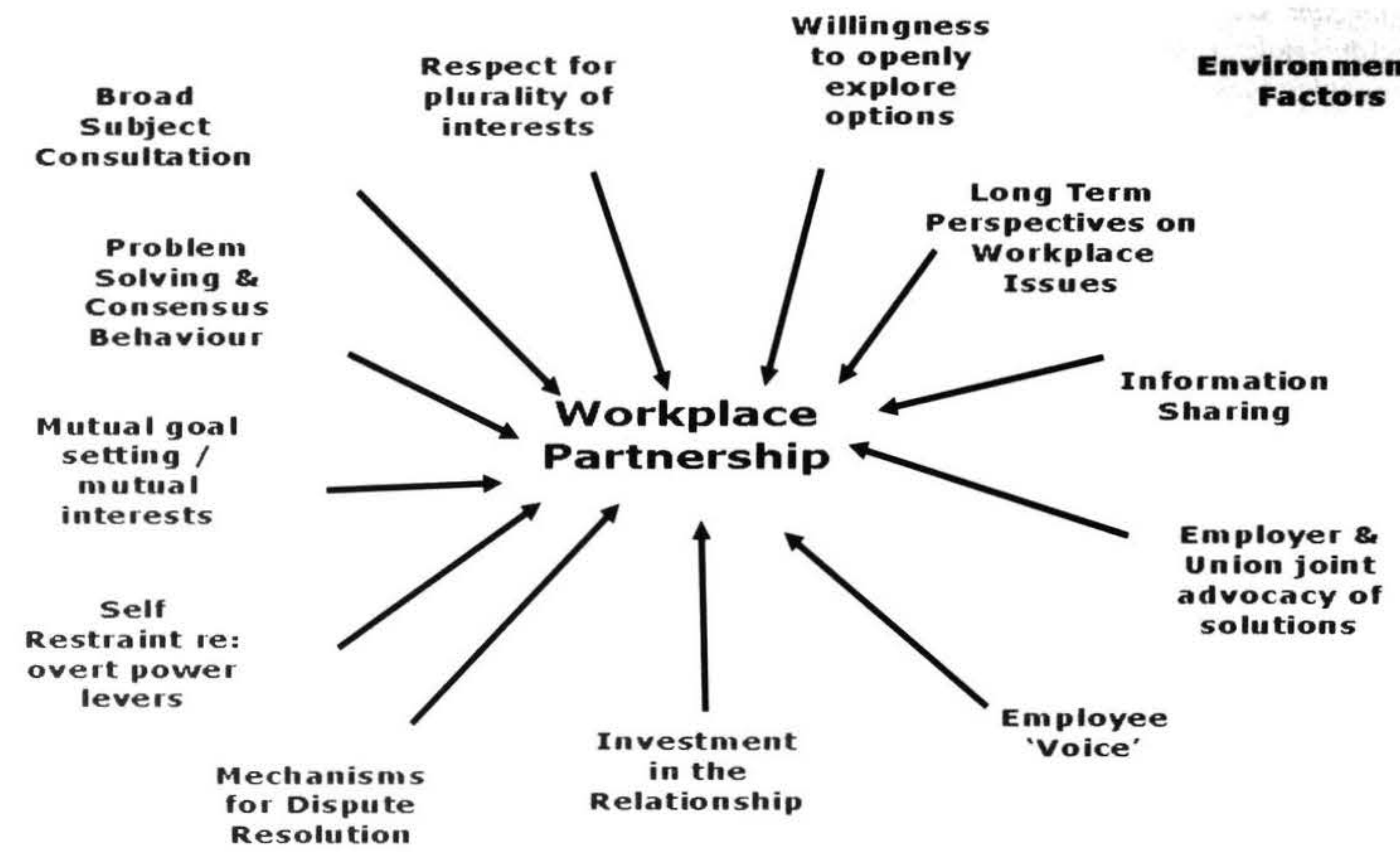

A survey was designed based on the theoretical model. The target population was all employers who, at July 2005, had single-employer collective employment agreements registered with the DOL, and representatives of the trade unions who were party to those agreements.

The DOL provided the research team with access to the database containing details of registered collective agreements and parties to those agreements, and also to an existing mail-out database. The database was checked and updated to optimize accuracy and likely returns.

An "online" survey tool was used in the development and conduct of the survey. Two draft surveys were developed; employers and union representatives undertook different but complementary surveys. All potential respondents (employer and union representatives) were sent a letter outlining the purpose of the survey and instructions for accessing the online survey site. The survey population consisted of 904 employers, and 189 union representatives from 52 unions. For the employer survey, 201 responses were received, for a response rate of 22.3 percent. For the union survey, 70 responses were received, for a response rate of 37 percent.

A limited list of targeted interview participants was selected from respondents who provided their details to be contacted for follow-up. Twenty employers and five union officials were selected for follow-up interviews, and these were conducted in November 2005.

\section{Survey Results}

The employer and union representatives who responded to the targeted survey represented a broad profile of New
Zealand industry by sector, size and location. Employers with collective agreements on the whole tend to have larger than average workforces and, accordingly, twothirds of respondent employers had workforces of more than 100 employees.

The results which follow are focused on and ordered as:

- The level of awareness of the concept and practice of workplace partnership;

- The extent that employers and unions are willing to partner with each other and the barriers to partnering; and

- The extent of workplace partnership practice and where and when it happens.

Awareness of Workplace Partnership

To gauge awareness of the concept of union-management workplace partnership, employers were asked whether they had had any experience, in terms of formal processes, with a range of what are generally seen as collaborative practices - "mutual gains bargaining or workplace partnership with a union representing the organization's employees", and "workplace reform or consultative approaches to change management".

Just 12 percent of respondent employers indicated that their organizations had had any experience with mutual gains bargaining or workplace partnership with unions in a formal sense. One quarter indicated that their organizations had experienced workplace reform or consultation over change management. 
At a more perceptual level, 70 percent of the respondent employers believed that the employees of their organizations were in partnership with management, while 30 percent did not. Just half as many, 35 percent, believed that the union was in partnership with the management and employees of their organizations.

By contrast with the employers in the sample, a majority of union respondents, 58 percent, said that they had had experience with mutual gains bargaining or workplace partnership systems. About the same number, 61 percent, said that they had had experience with workplace reform processes or consultative approaches to change management.

It might be an accurate summary to say that a majority of union respondents and a minority - albeit a significant minority - of employer respondents have some familiarity with workplace partnership or the notion of unionmanagement cooperation in the workplace more broadly.

\section{Incentives and Barriers to Partnering}

The second dimension of workplace partnership examined is the willingness of union and management parties to engage in partnership and, on the other side of that coin, the barriers to partnering that are likely to be encountered.

Eighty-one percent of respondent union officials said that their union saw its role as being a strategic partner in the management of organizations in which members were employed. Of these, one half said that their union strongly endorsed that view, while the rest reported that official union policy was somewhat supportive. Fifty-two percent of union officials agreed "totally" with the statement "unions should be prepared to act in partnership with an employer where the employer is willing to do the same". Another 34 percent agreed "to some extent", while 15 percent disagreed entirely with that statement. In other words, 85 percent of respondent union officials were prepared, at least to some extent, to engage with employers in workplace partnerships, on a reciprocal basis.

Union officials' personal approaches to employers and collective bargaining are set out in Table 1 .

The picture that emerges from the data is of a group of union respondents overwhelmingly supportive of a partnership approach to union-management relationships, believing that that approach benefits both employees and the employer. Reciprocation by the employer is important to them, and they see the inclinations of the chief executive as pivotal in the development or not of workplace partnership. Employers disrespecting the role of the union, by bypassing officials and attempting to deal directly with employees, is a turnoff for these union officials. However, their support for partnership is pretty resilient despite sometimes encountering employer conduct and attitudes not conducive to partnership.

Certainly the picture is of a group of union officials who believe that the union has something to contribute to employing organizations, who believe that members would benefit from a collaborative relationship between employer and union, and who are ready to play their part if employers are willing to play their's.

Employers were asked why they deal with unions representing their employees. In multiple union situations, employers were asked to respond with reference to the union that represented the largest number of their employees. Their responses are set out in Table 2 .

Table 1: Union officials' personal approaches and beliefs.

\begin{tabular}{|c|c|c|c|}
\hline $\begin{array}{l}\text { 'Thinking about your personal views as a union/ association representative, } \\
\text { please describe the extent to which you agree or disagree with each of the } \\
\text { following statements.' }\end{array}$ & $\begin{array}{l}\text { To a large } \\
\text { extent } \\
\%\end{array}$ & $\begin{array}{l}\text { To some } \\
\text { extent } \\
\%\end{array}$ & $\begin{array}{l}\text { Not at all } \\
\%\end{array}$ \\
\hline A union's role is to maximize the direct benefits flowing to its members & 87 & 11 & 2 \\
\hline $\begin{array}{l}\text { Unions should use their bargaining power in an overt manner when required } \\
\text { to get what their members want from reluctant employers }\end{array}$ & 40 & 56 & 5 \\
\hline $\begin{array}{l}\text { Unions should take a longer term view and be prepared to compromise even } \\
\text { when they have more bargaining power than the employer }\end{array}$ & 29 & 56 & 15 \\
\hline Unions and employers have more common interests than conflicting interests & 35 & 53 & 11 \\
\hline Industrial action is best avoided unless absolutely necessary & 85 & 11 & 3 \\
\hline $\begin{array}{l}\text { Unions should resist employer attempts at 'changes' which may disrupt the } \\
\text { working lives of members }\end{array}$ & 35 & 58 & 6 \\
\hline It is $\mathrm{OK}$ for union leaders to have a close social relationship with management & 8 & 54 & 38 \\
\hline Most employers want to do the right thing by their employees & 5 & 84 & 11 \\
\hline Most employers want to do the right thing by the union & 2 & 55 & 44 \\
\hline $\begin{array}{l}\text { A union should compromise its interests a little rather than damage its } \\
\text { relationship with an employer }\end{array}$ & 6 & 43 & 51 \\
\hline Having a union involved enhances an employers efficiency and productivity & 75 & 22 & 3 \\
\hline
\end{tabular}


Table 2: Why employers deal with unions.

\begin{tabular}{|l|l|l|}
\hline $\begin{array}{l}\text { 'Could you please indicate whether you mostly agree or mostly disagree with each } \\
\text { of the following statements about why your organization has a relationship with } \\
\text { this union.' }\end{array}$ & $\begin{array}{l}\text { Mostly agree } \\
\%\end{array}$ & $\begin{array}{l}\text { Mostly } \\
\text { disagree } \\
\%\end{array}$ \\
\hline Because it can't easily be avoided & 77 & 23 \\
\hline Because our employees want it & 83 & 17 \\
\hline Because 'it has always been that way & 63 & 38 \\
\hline Because it is beneficial to the organization & 41 & 59 \\
\hline Because the law requires it & 65 & 35 \\
\hline
\end{tabular}

While a significant minority of employers acknowledge that union involvement may be beneficial to the organization, this is not a driving motivation to deal with a union for most employers. When asked to choose which of the reasons listed in Table 2 was "the single most influential reason" for dealing with the union, just 11 percent of employers nominated "because it is beneficial to the organization".

One necessary ingredient for successful partnership, but not a sufficient one on its own, is acceptance of a diversity of interests in the workplace and the legitimacy of an independent voice for employees. In this respect, it is noteworthy that 83 percent of employers said that they dealt with a union because that was what their employees wanted, and 43 percent nominated this as the primary reason for dealing with the union.

Precisely 40 percent of respondent employers supported workplace partnership as likely to help New Zealand business, while 60 percent did not, and the responses show some interesting patterns by demographics. employer attitudes, and their reported experiences in dealing with unions.

There were no marked patterns to employers' expressed support for union-management partnerships as being beneficial for business by nature of the employer's business or industry classification, although respondents representing state agency employers were marginally more likely to endorse partnership. Perhaps surprisingly, there were no patterns associated with the nature or scope of competition in markets for employers' products or services, or by self-reported indicators of market or cost pressures.

Employers in Canterbury were most likely ( 70 percent) to believe that the promotion of workplace partnership

On the other side of the coin, employers who said that they always "tried to protect the organization's interests by limiting the union's input to just wages and basic employment conditions, not management issues" were less likely to endorse the benefits of partnership (27 percent endorsement) than those who said that they took that approach only sometimes or not at all (50 percent endorsement). would benefit New Zealand businesses, with those in Auckland least likely ( 28 percent) of employers in major centres.

Whereas union officials' support for partnership was directly correlated with their attitudes and beliefs, to some extent withstanding negative experiences with employers, employers' support or not for partnership was more directly and solely tied to their experiences with unions.

To a considerable extent, employers' attitudes to workplace partnership are reflected in their approaches to collective bargaining, and that is unsurprising given the central role of collective bargaining in union-management relations under the Employment Relations Act.

It is instructive to note relationships between some bargaining practices that would normally be associated with a "good faith" or "interest based" approach and a willingness to endorse workplace partnership as being beneficial for business.

For example, employers who said that they always preferred to "brainstorm" with the union over a range of options before taking positions on how particular issues should be settled or dealt with were far more likely to endorse the benefits of partnership $(80$ percent endorsement) than those who only sometimes ( 38 percent endorsement) or never did so ( 28 percent endorsement).

Employers who said that they always "worked to find areas of mutual interest to the organization and the union and to jointly develop proposals in those areas" were more likely to endorse the benefits of partnership (71 percent endorsement) than those who said that they only sometimes ( 27 percent endorsement) or never ( 13 percent endorsement) did so.

A commitment to relationships is a key ingredient in successful partnerships. So it comes as no surprise that employers who said that they were willing to agree to some collective bargaining proposals that they did not particularly like in order to build a better relationship with the union were much more likely to endorse the benefits of partnership ( 49 percent endorsement) than those who said that they were never willing to do that $(3$ percent endorsement). 
Table 3: Employer attitudes to union involvement.

\begin{tabular}{|l|l|l|}
\hline $\begin{array}{l}\text { 'Please describe the attitudes or policies of those in your organization mainly responsible } \\
\text { for dealing with the union.' }\end{array}$ & $\begin{array}{l}\text { Agree } \\
\%\end{array}$ & $\begin{array}{l}\text { Disagree } \\
\%\end{array}$ \\
\hline We would like to see the union more fully involved in the organization & 11 & 89 \\
\hline The union is a legitimate representative of employees, but not part of our team & 77 & 23 \\
\hline The union is a source of conflict and division in the organization & 38 & 62 \\
\hline The union officials will do the right thing by our organization & 37 & 63 \\
\hline We would prefer to deal less with the union and more directly with employees & 76 & 24 \\
\hline We have an effective relationship with the union and are keen to keep it the way it is & 78 & 22 \\
\hline Our relationship with the union is tense and unproductive & 16 & 84 \\
\hline $\begin{array}{l}\text { We consult with the union before making decisions that significantly impact the } \\
\text { organization and the way we operate }\end{array}$ & 72 & 28 \\
\hline $\begin{array}{l}\text { We would rather compromise our interests a little than damage our relationship with the } \\
\text { union }\end{array}$ & 50 \\
\hline $\begin{array}{l}\text { We would trust the union to keep commercial information about our organization } \\
\text { confidential }\end{array}$ & 59 \\
\hline The union is a problem we could do without & 30 \\
\hline Having union involvement enhances the operation of our business & 41 \\
\hline The union creates a better workplace environment for employees & 23 \\
\hline $\begin{array}{l}\text { Employees will not achieve anything through the union that management would not have } \\
\text { given them anyway }\end{array}$ & 30 \\
\hline The union improves the organization's competitive position & 50 \\
\hline
\end{tabular}

Employers were asked to react to a series of statements designed to gauge their attitudes to unions and collective bargaining. Some of these, principally dealing with employers' preferences regarding unions, and the statistics on the percentages of respondent employers who agreed and disagreed with each statement, are set out in Table 3.

There were some interesting and statistically significant correlations between attitudes to union involvement and endorsement of workplace partnership as being beneficial to business. For example, employers who said that they consult with the union before making significant decisions - what many would consider a fundamental of workplace partnership - were much more likely to endorse the benefits of partnership $(51$ percent endorsement) than those who don't (14 percent endorsement). Employers who agreed that they would compromise their interests a little rather than damage their relationship with the union were more than twice as likely to endorse the benefits of workplace partnership (56 percent endorsement) than those who said that they would not compromise ( 25 percent endorsement).

Employers who agreed that the union creates a better workplace environment for employees were more likely to endorse partnership (67 percent endorsement) than those who did not agree with that statement ( 29 percent endorsement). Those who were prepared to go beyond that to say that having union involvement enhances the operation of the business were far more likely to endorse the benefits of workplace partnership ( 79 percent endorsement) than those who did not agree with that statement ( 28 percent endorsement).

Again, it is clear that employers who have the inclination to be relatively open in their dealings with unions, who are prepared to take the risks associated with openness and trust, and to pay the costs associated with protecting and building the relationship, are more often appreciative of the value of partnership than those who don't have those inclinations and experience.

It is also clear that employers' approach to partnership is a largely pragmatic one, not an ideological thing. The employers who most endorse the value of partnership are those who say, from their experience, that it not only benefits their employees, but that it benefits the organization as well.

The study extensively recorded the self-reported attitudes and behaviours of employers. But union officials were also asked about employers' attitudes and behaviours that they had encountered, and that impact on the chances of establishing collaborative relationships. These results are presented in Table 4. 


\begin{tabular}{|c|c|c|c|}
\hline $\begin{array}{l}\text { 'Please describe the extent to which you have encountered the } \\
\text { following problems in trying to establish effective } \\
\text { relationships with employers.' }\end{array}$ & $\begin{array}{l}\text { A consistent } \\
\text { problem } \\
\%\end{array}$ & $\begin{array}{l}\text { Sometimes } \\
\text { a problem } \\
\%\end{array}$ & $\begin{array}{l}\text { Generally not } \\
\text { a problem } \\
\%\end{array}$ \\
\hline $\begin{array}{l}\text { Employers attempt to deal directly with employees even when } \\
\text { the union has an established role }\end{array}$ & 16 & 53 & 31 \\
\hline Employers are not open to collaborative approaches & 11 & 60 & 29 \\
\hline $\begin{array}{l}\text { Employers assert a right to run their business however they } \\
\text { choose to without "union interference' }\end{array}$ & 23 & 44 & 34 \\
\hline $\begin{array}{l}\text { Short-term economic imperatives are the single most important } \\
\text { factor to employers }\end{array}$ & 29 & 53 & 18 \\
\hline $\begin{array}{l}\text { Employers do not genuinely want employees or the union to } \\
\text { have a real say in the running of the organization }\end{array}$ & 36 & 51 & 14 \\
\hline $\begin{array}{l}\text { Employers undermine the union's attempts at 'partnership' by } \\
\text { establishing direct employee participation schemes that exclude } \\
\text { the union }\end{array}$ & 15 & 42 & 42 \\
\hline $\begin{array}{l}\text { Employers are not really interested in any value that active } \\
\text { union involvement could add to the business }\end{array}$ & 23 & 53 & 23 \\
\hline $\begin{array}{l}\text { Employers insist on treating the union and union officials as } \\
\text { "outsiders" rather than as an integral part of the organization }\end{array}$ & 35 & 39 & 26 \\
\hline
\end{tabular}

To summarize the theme of Table 4 , about three-quarters of union officials said that they either consistently or sometimes encountered a range of attitudes amongst employers that would not ordinarily be thought of as being conducive to establishing collaborative relationships.

Most union officials had, from their perspectives, to deal - occasionally or often -with employers who were not open to collaboration, who didn't believe that unions had anything to contribute, who did not welcome union input into decision-making, who regarded them as outsiders to the management-employee relationship, and who essentially attempted to side-step the union and diminish its role.

These are not insignificant attitudinal barriers confronting a union secking to establish a partnership relationship with an employer. And it is well to recall that a significant minority (40 percent) of union respondents said that they sometimes encountered resistance to their efforts to forge partnership arrangements with employers from their own members and delegates as well.

Without diminishing the barriers to partnership, the statistics can also be interpreted more hopefully. It is noteworthy that a substantial minority of union officials reported that they were generally not encountering these negative attitudes as a problem in establishing effective relationships with employers.

\section{Where is Workplace Partnership Happening?}

Generally speaking, demographics do not emerge as a reliable predictor of the practice of workplace partnership. There were some suggestive patterns but no statistically significant variations by the nature of the employing organization, by industry classification, or by workforce size. Partnerships were more likely to be reported by employers with just one or a few worksites than by employers with many sites, and employers in New Zealand's two major cities were the least likely to report being in partnership with a union, although again these relationships were not at a statistically significant level.

All in all, while there were some interesting patterns to the demographics, there is nothing in the data to suggest that partnership is assured of flourishing in one particular location or industry or market or plant configuration, but doomed to fail in others. The link between reported partnership and demographic variables is simply not that strong. It seems reasonable to conclude that there is potential for workplace partnership pretty much anywhere that union and management commit to it.

Employers were also asked how long they had been a party to collective agreements with the union (or, again, the union representing the largest number of their employees where the employer dealt with more than one union). The percentages of employers reporting partnership relationships with unions according to length of time dealing with the union are illustrated in Figure 2. 
Figure 2: Partnership by years dealing with the union.

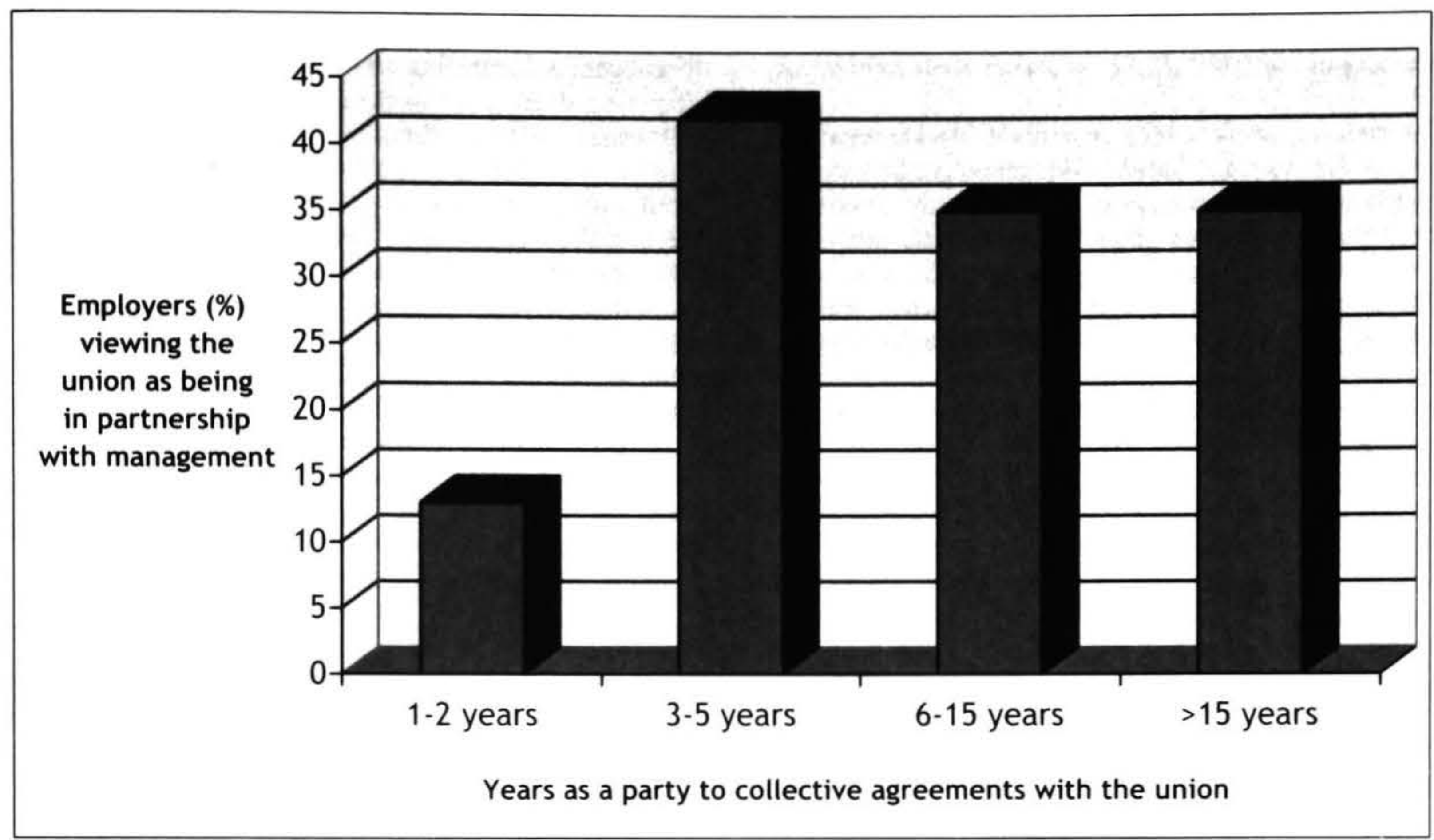

There is obviously no consistent relationship between felt partnership and length of time working together in the sense that it cannot be said from the data that the longer the period a union and management work together the more likely they are to develop a partnership relationship. However, what is clear from Figure 2 is that a sense of partnership is not prevalent amongst employers in new bargaining relationships with unions. What is apparent on the face of the graph is that partnership takes some time to build. Indeed, 80 percent of employers who said that the unions with which they dealt were in partnership with management and the employees had been parties to collective agreements with those unions for six years or more. And indeed all but one employer describing the union-management relationship as a partnership had dealt with the unions for three years or more.

To summarize, an employer dealing with a single union representing a high percentage of the employer's employees, with the opportunity to develop over time a trusting relationship with a credible union official would seem to reflect some of the key ingredients in the recipe for a successful workplace partnership.

\section{Conclusion}

The deliberate focus of this study was employers with single-employer collective agreements. Employers with multi-employer documents, largely in the public sector, were not included.

Among employers with single employer collectives, the findings suggest that the most likely situation in which to find workplace partnership-type engagement in New
Zealand at this time is an employer dealing with one principle union for a single employer collective agreement covering employees throughout the organisation. There are otherwise no very clear patterns by industry or area of the country.

There are few examples of "pure" workplace partnerships evident in this research. In the sub-samples of employers and union officials who report either being in partnership or being inclined towards partnership, actual bargaining and other workplace relations practices tend to be a mixture of some behaviours and attitudes that would be associated with a partnership approach and other behaviours and attitudes that would normally be associated with, perhaps, a more traditional, competitive approach to union-management relations.

It can be inferred from the research that most workplace partnership in New Zealand, at least in the private sector, is "self-taught" or experimental, is not strategically based on a cohesive concept or "theory" of partnership, and is "incomplete" in the sense noted above - parties mix partnership behaviours with more traditional ways of relating to one another. Beyond bargaining and beyond other statutory associations and forums (health and safety committees, for example) no consistent pattern of cooperative relationships or forums emerged, although there were a small number of notable exceptions.

Workplace partnership in New Zealand where it does occur, even in limited form, appears to take time to develop. It also appears to involve some natural ordering of circumstances involving (a) a mature collective bargaining relationship; (b) reasonable relationships between individual representatives of the employer and 
the union; and, (c) a catalyst initiative from one side or a circumstance requiring broader co-operation or joint discussion outside of bargaining and the usual day-to-day interactions.

One in every three employers surveyed is interested in partnership-type approaches with unions, albeit that the evidence suggests that what they currently envisage is something less than an all-embracing partnership. Many union officials suspect that employers often want partnership "only on their terms". It is clear from the research that employers" views of workplace partnership are very pragmatic and experience-based. Employers who have had good experiences when trying to be more open with a union tend to be interested in partnership; those who have not. or who have had a bad experience, are less interested or are opposed.

The majority of employers surveyed have what might most accurately be described as a "limited" view of unions. Most respect the right of employees to have representation and accept the role of the union in representing employees. However, relatively few are prepared to go so far as to acknowledge the union as "part of our team." As a result, a lot of union officials report facing a range of attitudes and behaviours from employers that only encourage traditional "position taking" in response.

The experiences and inclinations of on-the-ground union officials are mixed. A minority of less than a quarter think that collaboration with employers is ideologically wrong and a betrayal of the membership. A second group is still dealing with bad experiences in the relatively recent past and these union officials are cautious with many employers with whom they deal, but nonetheless generally open to partnership under the right circumstances. A minority are fully embracing workplace partnership concepts in theory and in practice.

On the whole, however, the data suggest that a significant majority of the union officials surveyed are supportive of partnership approaches on a reciprocal basis (that is, where employers are open to the same) and believe that partnership would benefit their members, the employer, and the New Zealand economy.

Since the shakeout in the early 1990s, the coverage of "real" collective bargaining between unions and employers has remained fairly stable, with only modest growth, despite a decade of hostile legislation and half a decade of quite supportive legislation. That seems unlikely to change substantially as long as legislation allows for, but does not mandate collective bargaining. Accordingly, the realistic ambit for expansion of partnership is the population of existing collective bargaining relationships

That does not mean that the nature of legislation has no bearing on the matter. The research does support the notion that "good faith" bchaviours in collective bargaining, if observed by both parties, are more likely to lead to further open relationships between the parties. What the legislation may actually do these days is not so much determine the spread or shrinkage of collective bargaining, but set the "tone" for the collective bargaining that does exist. In this sense, the ERA goes to the nature of collective bargaining and provides a platform for promoting degrees of workplace partnership over more traditional, competitive styles of interaction.

Finally, if effective collective bargaining is accepted as a key pathway to broader workplace partnership, then government via the DOL has a key role to play. To the extent that the focus in the past has been on interventions in collective bargaining when things go wrong (as they sometimes do) and providing effective dispute resolution, then perhaps the role in the future should go further. The extension would be to promoting improved understanding amongst the industrial parties in New Zealand of 'mutual gains' (or similar) bargaining practices and of broader workplace partnership practices. Perhaps interventions should not end when immediate outcomes are reached in a collective bargaining dispute. Instead this could be followed with longer term assistance to get the parties behaving in a manner whereby the next time bargaining occurs another dispute is avoided. This change in focus is already emerging in the proactive mandate that the DOL has accepted, for example as the role and guiding philosophy of the Mediation Service, and in the establishment of the PRC.

\section{Future Research}

Among other things, this research has indicated that there is occurring a gradual transition in the way in which some New Zealand employers and unions are interacting with one another, and that this happens most obviously as collective bargaining relationships mature. From employers' perspectives, it appears to be occurring largely pragmatically, while most union officials are more inclined to believe that partnership behaviours and attitudes benefit workers, employers and productivity.

The study opens up a number of avenues for further research, some of which is already in train. The author and colleagues at Otago University are already exploring more closely the links between partnership attitudes and behaviours and employers employment relations ideologies. Collaborative work with colleagues at Massey University exploring employers' attitudes to collective bargaining is also relevant. However, other research opportunities abound.

With exceptions, it is fair to conclude that most movement towards the adoption of partnership behaviours and attitudes has occurred in New Zealand over the past 15 years, with some acceleration since 2000 . Longitudinal replication of this research tracking changing attitudes and behaviours makes some sense.

Union-management partnership is not something valued for its own sakes. It is seen by proponents to enhance employment relationships and the workplace experience, as well as to benefit employer, industry and national productivity and competitiveness. While the present research has tested these outcomes at the level of 
participant perspectives, hard evidence on partnership outcomes in New Zealand is essentially limited to case studies sponsored and published by the PRC. There is room for much more.

Conventional wisdom holds that partnership behaviours and attitudes are most likely to be found in singleemployer, single-union collective bargaining relationships. The scope of this research was defined by that supposition, although as a matter of settling priorities rather than ruling out partnership at other levels of engagement. As multi-employer and multi-union bargaining and documents have assumed greater importance on the industrial landscape, research into bargaining behaviours and attitudes, and outcomes, at those levels is now also required.

\section{References}

Ackers, P. and Payne, J. (1998). British trade unions and social partnership: rhetoric, reality and strategy. The International Journal of Human Resource Management 9(3), 529-550.

Bakke, E.W. (1946). Mutual Survival: The Goal of Unions and Management. New York: Harper \& Brothers.

Ballard, M. and McAndrew, I. (2006). Illustrated Report and Stocktake on Workplace Partnership in New Zealand. Wellington: Partnership Resource Centre, New Zealand Department of Labour.

Brannen, P. (1983). Authority and Participation in Industry. London: Batsford.

Clegg, H.A. (1979). The Changing System of Industrial Relations in Great Britain. Oxford: Blackwell.

Flanders, A. (1974). Management and Unions: The Theory and Reform of Industrial Relations. London: Faber.

Guest, D.E. and Peccei, R. (2001). Partnership at work: Mutuality and the balance of advantage. British Journal of Industrial Relations. 39(2), 207-236.
Harbridge, R. (1988). Whatever happened to second tier settlements? A survey of settlements under the Labour Relations Act 1987. New Zealand Journal of Industrial Relations 13(2), 143-156.

Harbridge, R. and McCaw, S. (1992) Award, agreement or nothing? A review of the impact of s.132(a) of the Labour Relations Act on collective bargaining. New Zealand Journal of Industrial Relations 17(2), 175-183.

Kochan, T.A. and Osterman, P. (1994). The Mutual Gains Enterprise: Forging a Winning Partnership Among Labour, Management, and Government. Boston: Harvard Business School Press.

Marchington, M. and Wilkinson, A. (2000). Direct participation. In Bach and Sisson, K. (eds) Personnel Management: A Comprehensive Guide to Theory and Practice. Oxford: Blackwell.

McAndrew, I. (1989). Bargaining structure and bargaining scope in New Zealand: The climate of employer opinion. New Zealand Journal of Industrial Relations 14(2), 133-148.

Wilkinson, A. (2001) Empowerment. In Poole, M, and Warner, M. (eds) International Encyclopaedia of Business and Management Handbook of Human Resource Management. London: ITB Press.

\section{Author}

Ian McAndrew

Senior Lecturer

Department of Management

University of Otago

P.O. Box 56

Dunedin

imcandrew@business.otago.ac.nz 